Acta Horticulturae et Regiotecturae 1

Nitra, Slovaca Universitas Agriculturae Nitriae, 2019, pp. 41-47

\title{
OBJECTS OF SMALL SACRAL ARCHITECTURE AND LANDSCAPE - CASE STUDY OF THE COMMUNE OF ŽIRANY
}

\author{
Veronika FUSKOVÁ,* Jakub FUSKA
}

Slovak University of Agriculture in Nitra, Slovakia

\begin{abstract}
This study aims to analyse existence, technical condition, origin and history of objects of small sacral architecture in the area of the Tribeč Mountains, specifically as a case study in the commune of Žirany. It defines different types of objects, mostly small chapels and crosses and specific phenomenon of small boxes with sculpture of saints installed on the front facades of residential houses. The study also focuses on the relation between small sacral architecture and existence of elements of greenery. As a result, the work presents a detailed description of the individual mapped elements and an overview map showing the objects in the cadastral area of Žirany.
\end{abstract}

Keywords: small sacral architecture, landscape, chapel, sculpture, cross

Small sacral architecture (SSA) forms specific roles in the Slovak country; it is a part of the cultural heritage, it co-creates and completes visual concept of most landscape structures, acts as a landscape accent and orientation point (Kotalík, 2004; Hájek a Bukačová, 2001) and it is also a form of sacral art as the means of expression of its inhabitants. From a historical point of view, the emergence and building of SSA is related to the Catholic Church; Holy Trinity and Virgin Mary are the most exquisite objects (Kleinová, 2017). An important element with respect to SSA is the presence of greenery. Tóth and Verešová (2018) mentioned the relation and interconnection of these elements in a whole, where the greenery (especially trees) completes the spiritual dimension of sacral elements. Every region has its specifics, SSA can differ in forms, shapes, materials, location of sacral objects and this study aims to show the examples of one of them.

\section{Material and methods}

\section{Map and software material}

A field survey was started by search of locations of SSA objects using the Basic Map of Slovakia in a form of the map client. The existence of these objects was subsequently verified in the field, objects were marked into personal google maps and by export of the data in a form of $\mathrm{KML} / \mathrm{KMZ}$ data were elaborated in the software QGIS to form a final map of locations.

Analyses of sacral objects were processed according to the Methodology of mapping of elements of small sacral architecture - methodology of project VEGA 1/0371/18 (2018). This methodology and the analysis procedure include definition of individual mapped elements by:
1. Location - cultural region, administrative region, city, cadastral area, street/road, GPS.

2. Spatial context - rural zone/residential zone of city/edge between.

3. Photo documentation - photo of whole object and its surroundings with spatial context or interesting views, photo of sacral object itself, photo of details.

4. Sacral objects - type of object, material, sizing, writing/ signs, fence and arrangements of surroundings, technical condition and degree of damage (0. perfect condition/ well maintained / reconstruction, damage $0 \%$; 1 . damage $1-10 \%$; 2. damage $11-25 \%$; 3. damage 26-60\%; 4. damage 60-69\%; 5. damage 70-100\%).

5. Greenery - 1. Trees - number, composition, taxon, trunk circumference $(\mathrm{cm})$, age defined by Šimek (2001), crown width $(\mathrm{m})$, height of tree $(\mathrm{m})$, landscape-architectural value (Machovec, 1987), health condition and degree of damage (Juhásová, 1999), notes; 2. Shrubs - number of shrubs/definition, composition, taxon, height in metres, notes.

6. Evidence in historical maps - using Maps of Europe Europe in $18^{\text {th }}$ and $19^{\text {th }}$ century.

\section{Results and discussion}

In total, ten SSA objects were mapped and analysed; five chapels, three crosses, small sacral boxes and a Lourdes cave were observed. According to methodology, all objects are located in the cultural region Dolná Nitra, Nitra region, commune Žirany, cadastral area Žirany.

Chapel of St. John of Nepomuk was built in 1843, foundation charter by Jozef Szórád is still preserved (Municipality of Žirany, 2010). It is situated in the edge

Contact address: Veronika Fusková, Slovak University of Agriculture in Nitra, Faculty of Horticulture and Landscape Engineering, Dean's office, Tulipánova 7, Nitra, Slovak Republic, +421 3764154 06, e-mail: veronika.fuskova@uniag.sk 


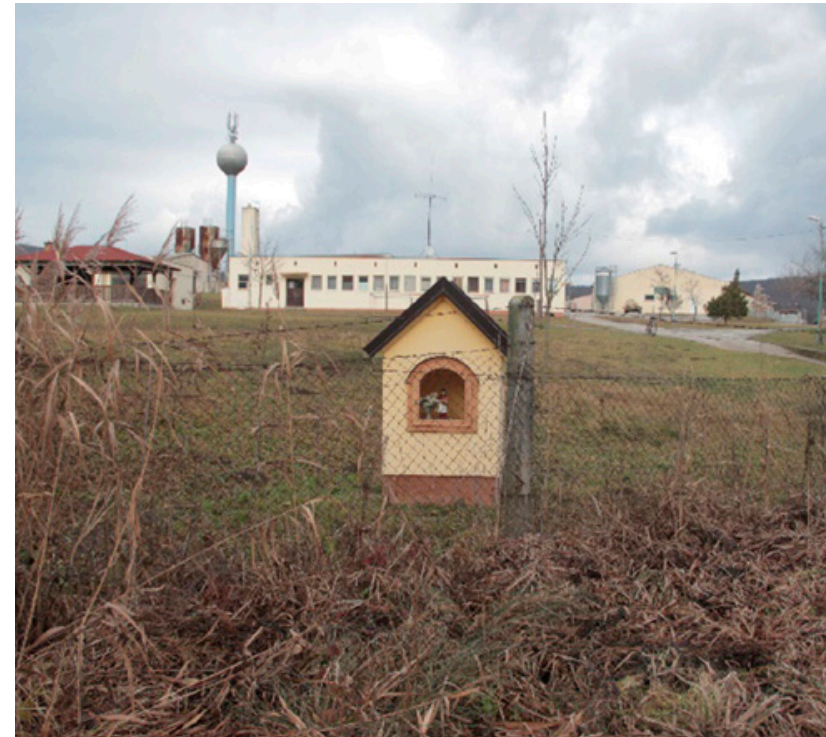

Figure 1 Chapel of St. John of Nepomuk Photo: Fusková, 2018

between rural and residential zone of the village on the premises of the Agricultural farm of the Slovak University of Agriculture (Fig. 1). Chapel's interior contains a small sculpture of St. John, small vase with flowers, cross and candles (Fig. 2). This object is built of brick, it is newly reconstructed and in perfect condition (value 0 for technical condition), with new painting, roofing and window. It is one of smaller chapels found in the area; it has $1.2 \times 1.2 \mathrm{~m}$ size in base and $1.6 \mathrm{~m}$ in height. The object is simple, painted in light yellow colour without any writing or decorative ornaments; its surrounding is also simple, without fence. In respect to greenery, this object stays without any, there are few trees newly planted, but they are part of the farm greenery without any historical context. Evidence in historical maps can be seen in the Map of Third Military Survey (Fig. 14) and the Military Survey of Hungary (Fig. 16).

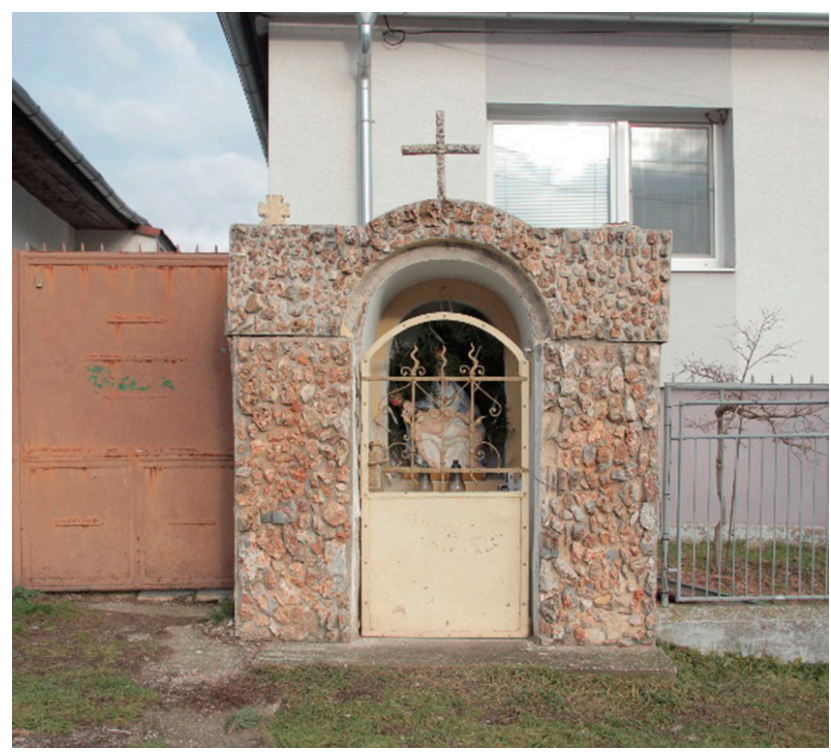

Figure 3 Chapel with Pieta Photo: Fusková, 2018

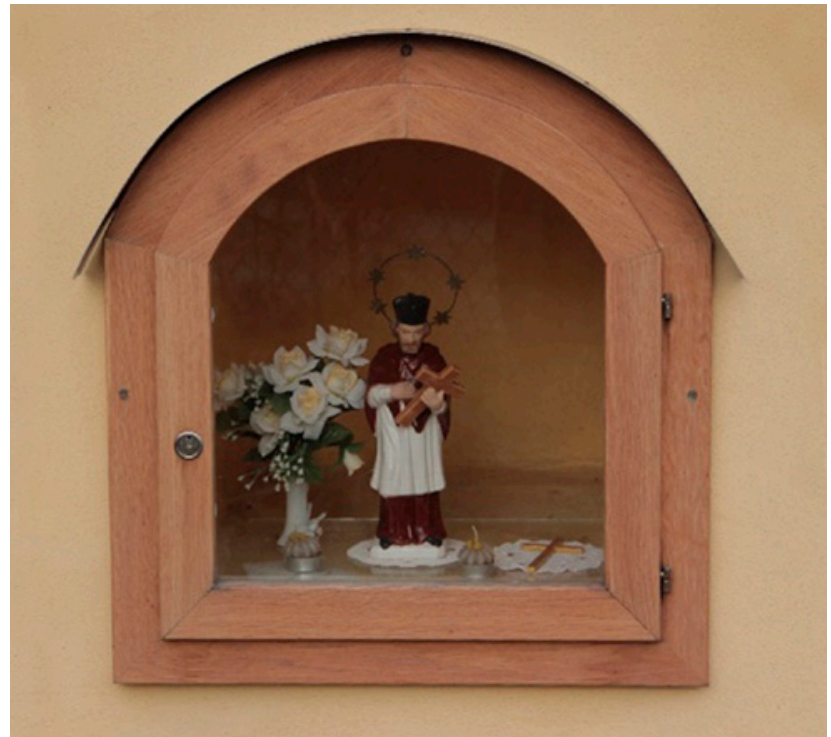

Figure 2 Chapel's interior

Photo: Fusková, 2018

Chapel with Pieta is situated in front of the residential house number 82 on the main road in the old residential area (Fig. 3). The object is built of brick, the front side of the chapel is lined with limestone, behind the pale-yellow metal doors there is a sculpture of a gracious appearance - Mother with dying Jesus (Fig. 4). The chapel is in good condition, it has no damage (value 0 for technical condition), the internal sculpture decoration is highlighted at night. In respect to sizing, the object has $1.6 \times 1.2 \mathrm{~m}$ in base and $2 \mathrm{~m}$ in height. There are no writings or ornaments, the chapel forms a part of the fence. There is no evidence of greenery and historical maps do not register the object. The estimated origin of this monument is the second half of the $20^{\text {th }}$ century.

Chapel of St. Wendelin was built in 1912 by Molnár family (Municipality of Žirany, 2010). It is situated in the yard of a village grocery store in the central zone of the residential area. The surrounding of the chapel is simple, it

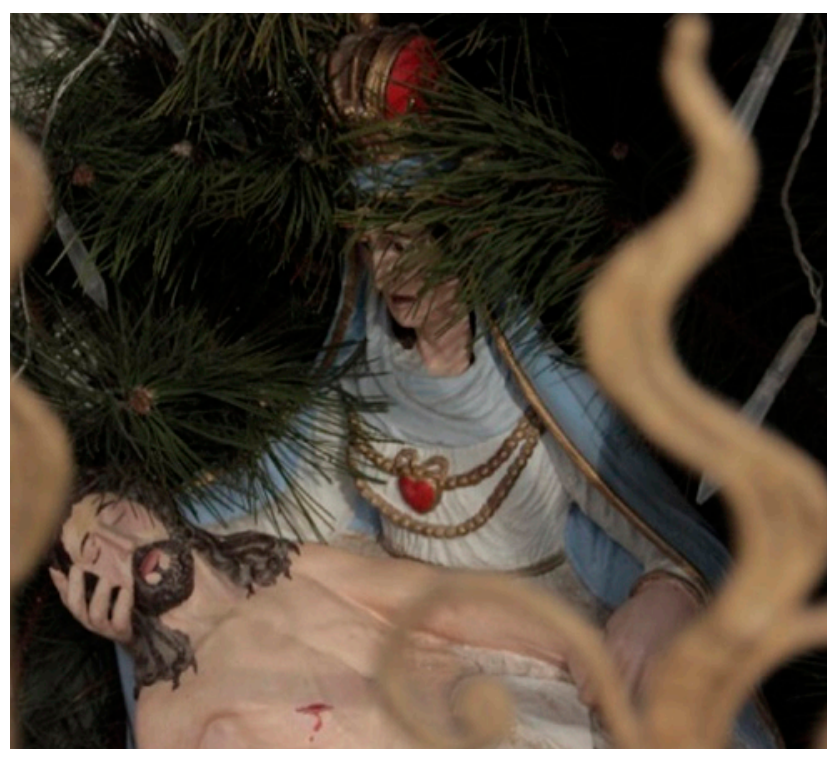

Figure 4 Detail of chapel's interior Photo: Fusková, 2018 


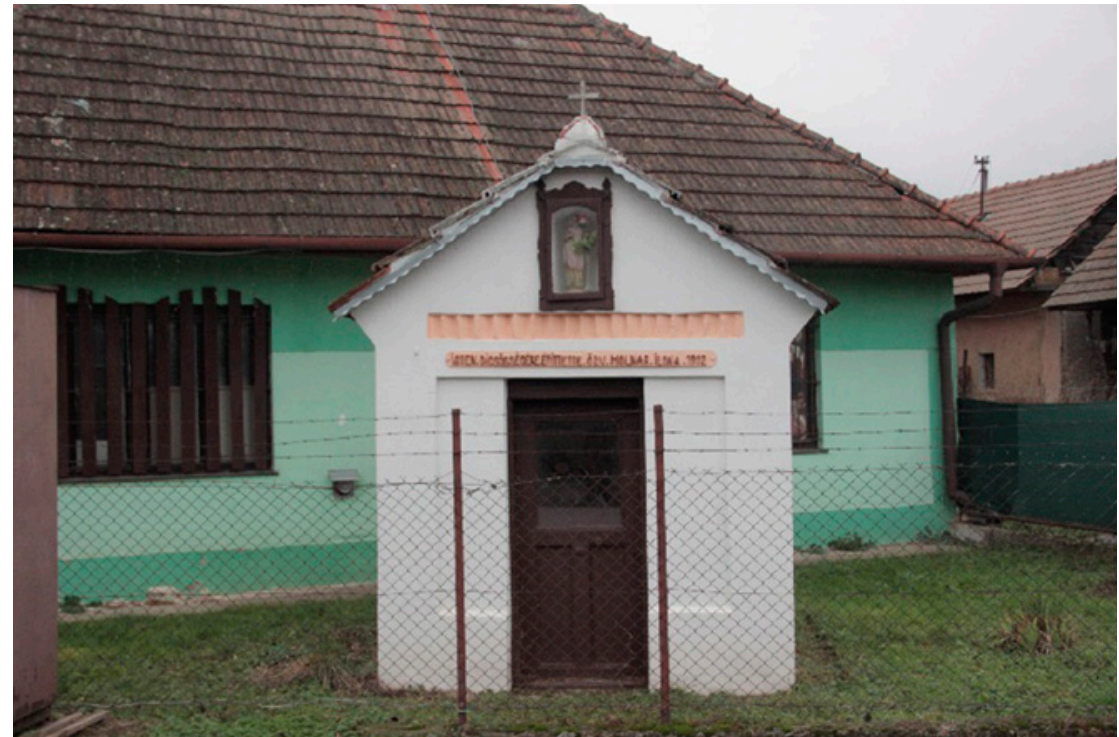

Figure 5 Chapel of St. Vendelin Photo: Fusková, 2018

faces the street, and both sides of the chapel are planted with Yucca, sp. (Fig. 5). The chapel is built of brick, painted in white colour, with roofing and dark brown wooden door. It has $1.5 \times 1.5 \mathrm{~m}$ in base size and $2.2 \mathrm{~m}$ in height. There is one-line writing on the light orange line: 'Isten. Dicsőségére. Épitette. Özv. Molnar. Ilona. 1912' (God. Glory. Built. Widow. Molnar. Ilona. 1912). Above writing there is an ornament painted in the same colour and more above a small wooden box with the statue of Virgin Mary (Fig. 6). Behind the door there is a sculpture of St. Wendelin dressed as a shepherd along with sheep. The object is well maintained,

without any sign of damage (value 0 for technical condition). Only greenery presented is the yucca plantation mentioned above. According to the data mentioned on facade, there cannot be any evidence in historical maps from $18^{\text {th }}$ and $19^{\text {th }}$ century, it was not also marked during the Hungarian Military Survey in 1941.

Chapel of St. Andrew the Apostle built in 1895 by Michal Dubnický (Municipality of Žirany, 2010) is situated in the rural zone in the Žirany cadastral area on the crossroad Jelenec - Kolíńany (Fig. 9). The object is oriented towards the landscape with a view line on the Tribeč mountain

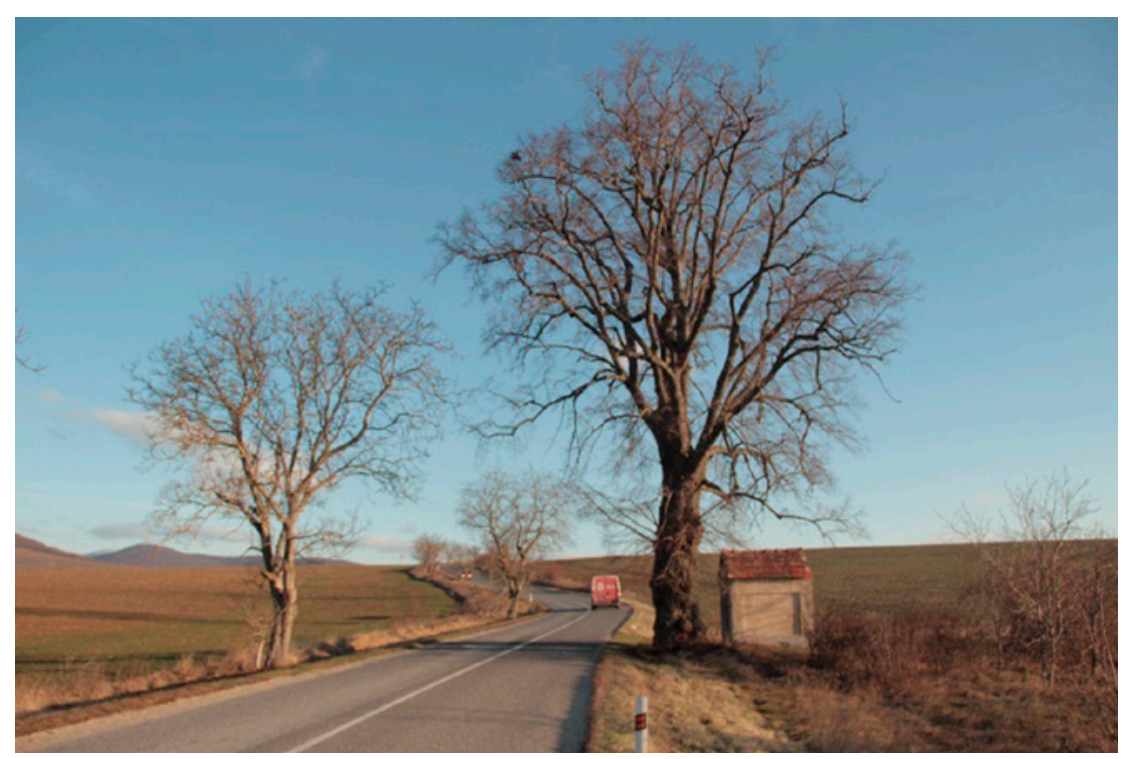

Figure 7 Chapel of St. Andrew the Apostle with tree Tilia cordata Photo: Fusková, 2018

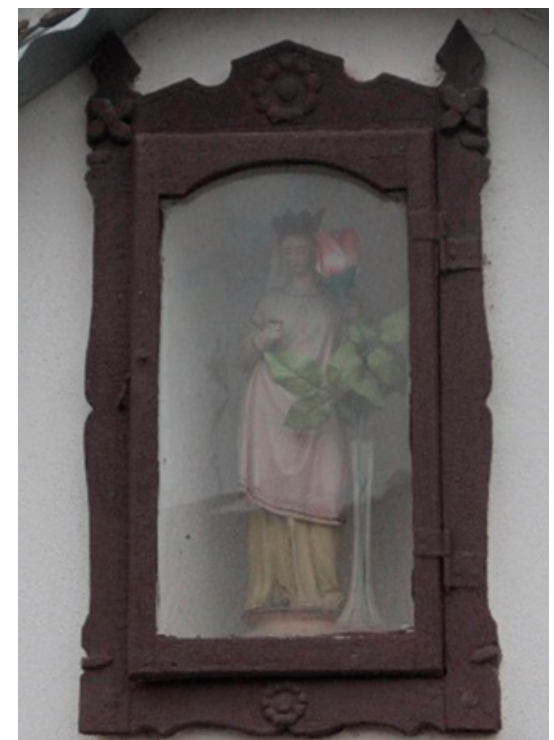

Figure 6 Detail of small box Photo: Fusková, 2018

range. It is built of bricks, with cement plaster, roofing and green metal doors. It has $1.5 \times 1.5 \mathrm{~m}$ in base size and 2 $\mathrm{m}$ in height. Its technical condition is not perfect, but it does not show significant signs of damage, except of graffiti on one side of the object, rather it may be a partial neglection resulting from the locality and high traffic pollution (value 2 for technical condition). In respect to greenery, this object is interesting as it is the only one adjacent to the growing tree. Tilia cordata, Mill. which grows at the right side of chapel has $272 \mathrm{~cm}$ in trunk circumference, $12.5 \mathrm{~m}$ of crown spread, $20 \mathrm{~m}$ in height, it represents value 5 (veteran) for its age by Šimek (2001), value 4 for its landscape-architectural value by Machovec (1987). According to Juhásová (2009) it represents $2^{\text {nd }}$ degree of health condition and degree of damage. The record of the chapel in

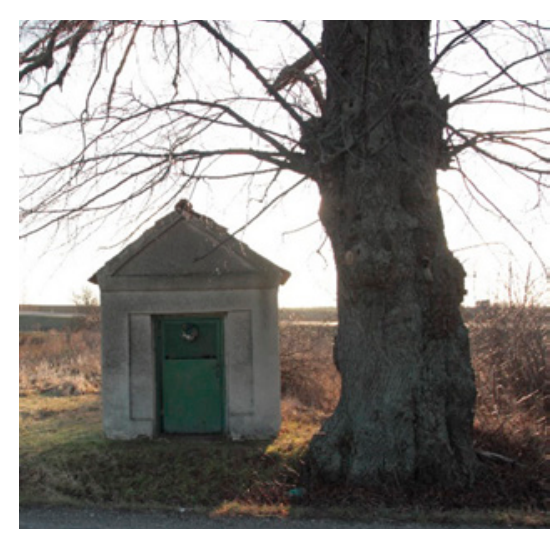

Figure 8 Detail of Chapel Photo: Fusková, 2018 


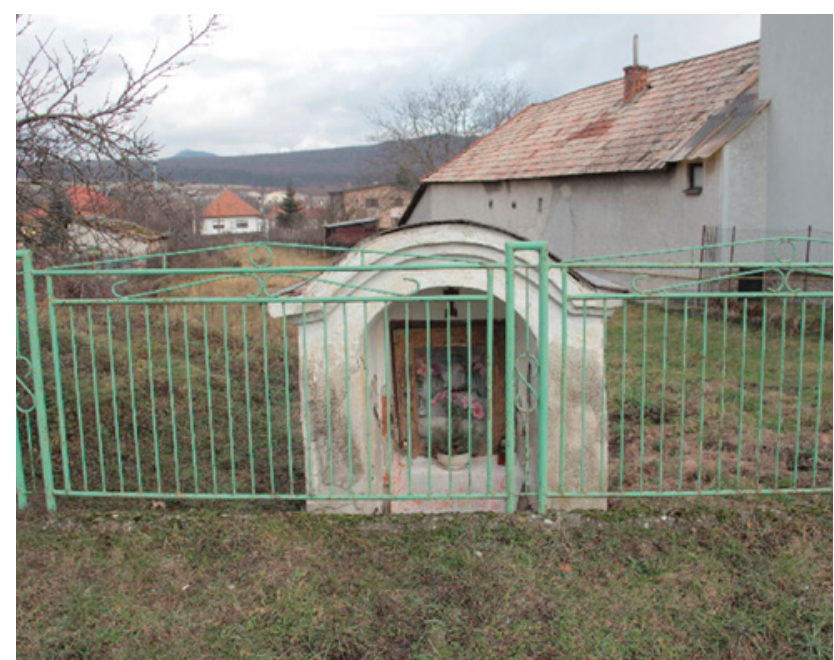

Figure 9 Chapel nearby main road Photo: Fusková, 2018

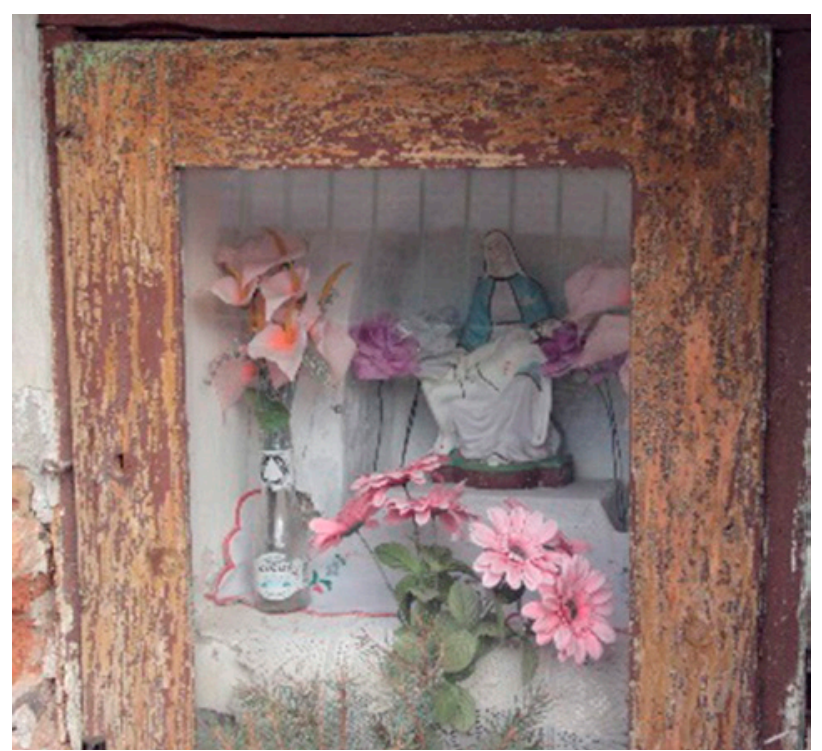

Figure 10 Detail of sculpture Photo: Fusková, 2018


Figure 12 Lourdes cave

Photo: Fusková, 2018

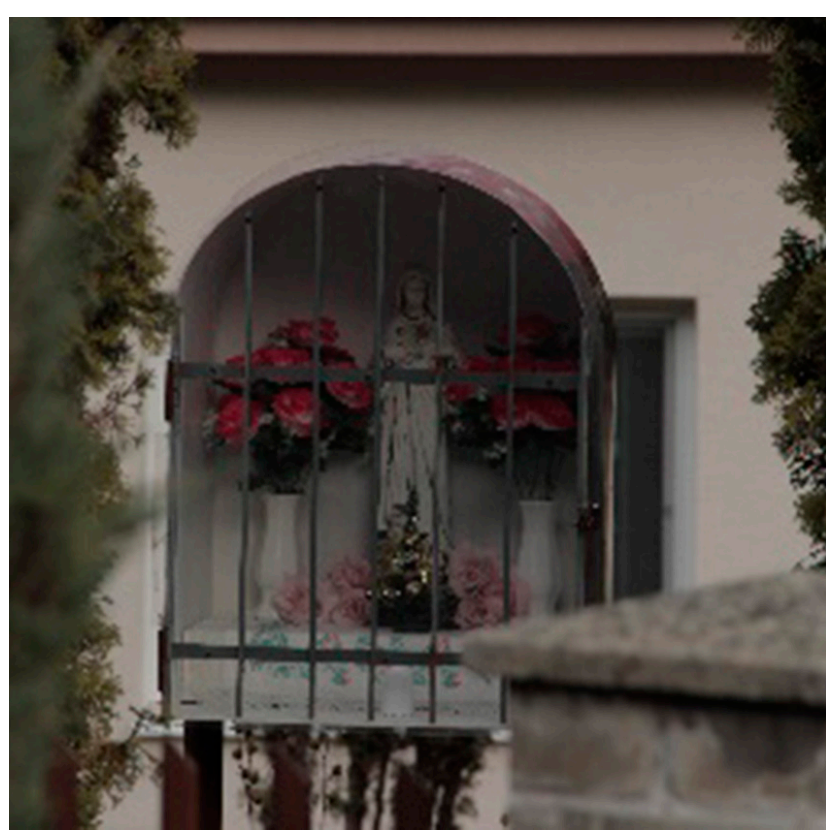

Figure 13 Small sacral box in residential garden Photo: Fusková, 2018

Figure 11 Example of small boxes with sculptures Photo: Fusková, 2018 


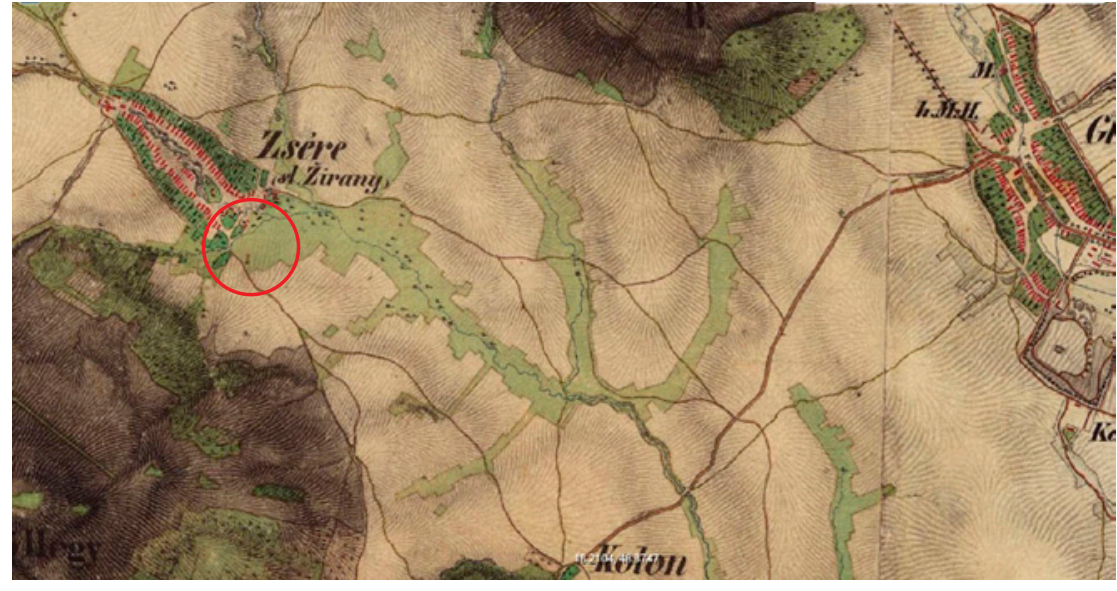

Figure 14 Second Military Survey of the Habsburg Empire (1819-1869) Source: Maps of Europe, Europe in $18^{\text {th }}$ and $19^{\text {th }}$ century

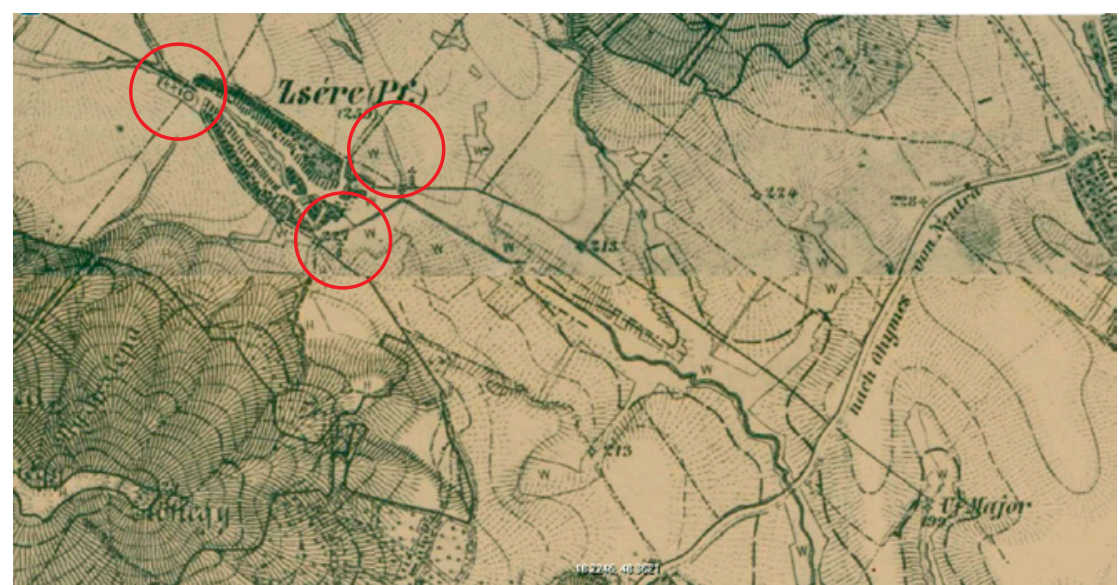

Figure 15 Third Military Survey of Habsburg Empire (1869-1887) Source: Maps of Europe, Europe in $18^{\text {th }}$ and $19^{\text {th }}$ century

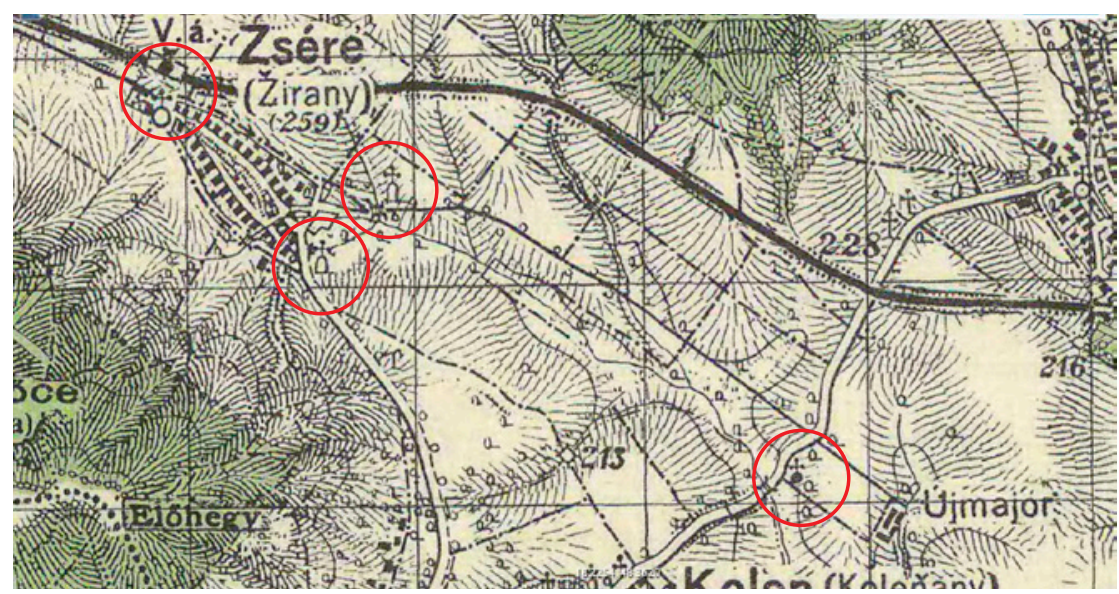

Figure 16 Military Survey of Hungary (1941)

Source: Maps of Europe, Europe in $18^{\text {th }}$ and $19^{\text {th }}$ century historical maps is visible at the map of the Military Survey of Hungary (Fig. 16).

Chapel situated near the main road (Fig. 9) has not any evidence in municipality chronicle. Deducing from the outlook, which the sculpture depicts inside the chapel, this one is also dedicated to the Mother with dying Jesus - Pieta (Fig. 10). It is a part of the private land property, facing towards the main road from which it is separated by a low green fence. This small chapel $(1 \times 1 \mathrm{~m}$ in base, $1.2 \mathrm{~m}$ in height) is built from bricks with vaulted roof and has no writing or ornaments at plaster. The technical condition is poor, the white plaster is much damaged, the bricks are visible in many places (value 3 for technical condition, damage tends to be $50 \%$ ). There are no trees tied to the object, a pair of fruit trees on the left side belongs to the neighbouring land. Evidence in historical maps shows that the chapel was marked during the Second Military Survey of the Habsburg Empire (Fig. 14) as well as later at the map of the Third Military Survey of Habsburg Empire (Fig. 15) and Military Survey of Hungary (Fig. 16), so it could have been constructed by the end of the $18^{\text {th }}$ or the beginning of the $19^{\text {th }}$ century.

According to the municipality chronicle there is also the Chapel of St. Urban in rural area in village vineyards built in 1795 (Municipality of Žirany, 2010). This chapel is not marked in the Base Map of Slovakia, there is also no evidence in historical maps, thus the object was not analysed.

Another sacral object - a Lourdes cave is located next to the church, it was built in 1927 by Valent Gál and his wife Carolina (Municipality of Žirany, 2010). Technically, it is in good condition, its interior contains sculpture of Virgin Mary of Lourdes. The object is built of stone, which also forms its exterior tiling, the base has dimensions of $2 \mathrm{~m}$ and height about $4 \mathrm{~m}$ (most of the building is massively covered by the plant Hedera helix, L.). There are three tables with writing in Hungarian, one speaks of the founder and the date, and others are the tables of gratitude of the Virgin Mary. The value for technical condition is 0 , in surroundings, Thuja occidentalis, L. is present. The trunk circumference is about $50 \mathrm{~cm}$ measured $20 \mathrm{~cm}$ above the ground, its age is valuated as 5 


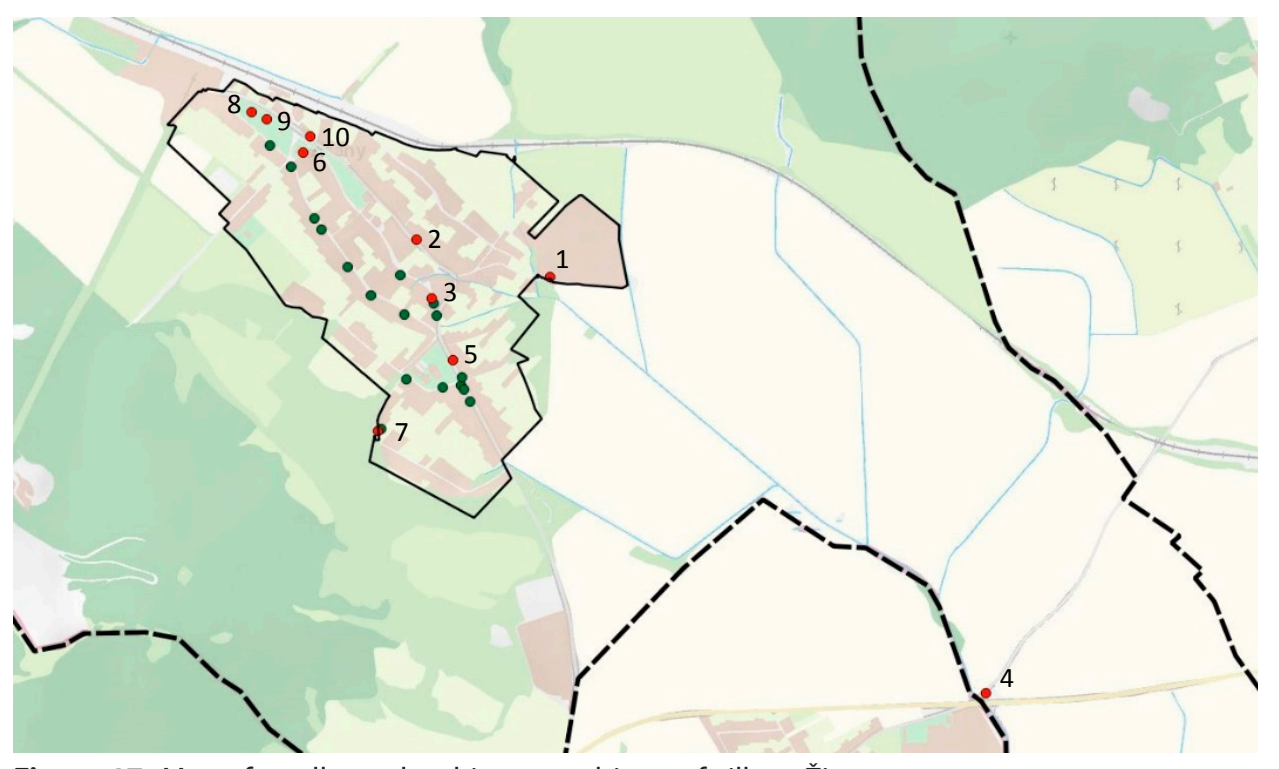

Figure 17 Map of small sacral architecture objects of village Žirany Source: made by the authors

(veteran), crown width is $1.6 \mathrm{~m}$, height of the tree is $8 \mathrm{~m}$. Landscape-architectural value is 3 and health condition and degree of damage is 3 , as a notice - the crown is wide and in upper parts starts to divide in more segments. The object was not marked during the Military Survey of Hungary in 1941.

Another type of SSA presented in the village is a cross. There were found three exemplars - the cross at the cemetery built in 1899 by Ján Vanyo (Municipality of Žirany, 2010), the cross at the cemetery from the first half of the $20^{\text {th }}$ century by Leopold Kupecsek - these crosses are marked at the Third Military Survey Map (Fig. 15) - and the stone cross from 1823 situated in the parish court near the main road. The last mentioned one has a writing table showing the data of origin and initials J.K.E.N - Josephus Kluch Episcopus Nitriensis (Joseph Kluch, bishop of Nitra). Originally, it stood between the church and the cemetery, in 1870 it was reconstructed by Ján Leopold (Municipality of Žirany, 2010). This cross is in average technical condition (value 3 ), the writing is hardly readable, the statue of Jesus is partly destroyed by weather conditions.

SSA in form of small boxes with sculptures of saints as a part of front facade of residential houses is one of the local specificities (Fig. 12); these objects were not found in neighbouring villages in such abundance and so many different shapes. In the Jelenec commune, there were 2 small facade boxes, in Hrnčiarovce only one object, in Beladice two small objects. There were mapped 18 objects of sacral facade boxes of different shapes and materials, predominately with sculptures of Virgin Mary or Jesus. The boxes were situated in central parts of facades between windows of the houses build in 1960's. The size of the window with the statue is almost the same as the windows on both sides of the box. One of the boxes (Fig. 13) was found in a residential garden in the form of a metal box $0.4 \times 0.4 \mathrm{~m}$ sized in base and $0.5 \mathrm{~m}$ in height, standing on two thin metal pillars $1.3 \mathrm{~m}$ above ground.

The analysis process according to the methodology of the VEGA project (2018) resulted in creation of the Map of small sacral architecture objects of the Žirany commune (Fig. 17) based on GPS of its location. One of the facts that can be discussed is that SSA objects mapped in the area (except one case) are not accompanied by greenery. Tóth and Verešová (2018) mapped SSA in relation to old trees and mentioned their cultural and spiritual value. In our territory, the missing presence of trees can be caused by location and its lack of space for greenery. Front yards of residential houses where chapels were found did not provide space for plantation. On the contrary, the chapel on the way to Jelenec acts as a landmark on the cross-roads; it is a part of the countryside thanks to the outlook axes. Along the road, an alley of trees was planted later, although it is assumed that the lime tree next to the chapel is older due to its growth compared to other alley trees. Small boxes with statues of saints mounted in the facades of residential homes remain a question. These elements were not found in any of the surrounding villages in the same form and number as they were in Žirany. The small altars of Virgin Mary and Jesus in houses of the 1960s related to the dedication of the dwellings, and huge number of objects incomparable with the surrounding area could be related to the numerous citizens of Hungarian origin in Žirany.

\section{Conclusion}

The methodology used in the analysis process allowed to verify and evaluate the condition of the SSA located in the cadastral area of Žirany. Mapping of objects revealed that there are 10 SSA objects; their origin was confronted with the help of the Municipality chronicle. The methodology allowed checking their technical condition and determining the type and condition of the greenery (trees) that form a single unit with objects of SSA.

\section{Acknowledgement}

The authors would like to thank The Ministry of Education, Science, Research and Sport of the Slovak Republic for supporting their research within the project VEGA $1 / 0371 / 18$. 


\section{References}

HÁJEK, T. - BUKAČOVÁ, I. 2001. Story of small monuments. $1^{\text {st }}$ ed., Studio JB, 2001, 137 pp. ISBN 80-900903-9-7.

JUHÁSOVÁ, G. 2009. Methodology of assessing the health status of woody plants, 2009.

JUHÁSOVÁ, G. 2009. Evaluation of trees. [online]. [cit. 10. 10. 2018]. Available at: <http://www.zahradaweb.cz/informace-z-oboru/ verejnazelen/Hodnotenie-drevin_s517x45050.html>

KLEINOVÁ, M. 2017. Small sacral architecture in the cultural landscape of Spiš : bachelor thesis (tutor: Tóth, Attila). Nitra : SUA, 2017, 30 pp + 97 pp. attachments.

KOTALÍK, J. 2004. The small monuments as a dimension of the cultural landscape. In Geschichte der kleinen Denkmäler: Von der Interesselosigkeit zur Faszination. Pressath: Bodner-Verlag, Studio JB, 2004, pp. 6-9. ISBN 3-937117-15-6.

MAP CLIENT ZBGIS. [online]. [cit. 1. 1. 2019]. Available at <https:// www.zbgis.sk/geodesy.sk>
MAPS OF EUROPE [online]. [cit. 4. 1. 2019]. Available at <https:// mapire.eu/en/ browse/composite/>

MUNICIPALITY OF ŽIRANY. 2010. Monuments in the village. [online]. (c) 2010- 2019. [cit. 6. 1. 2019]. Available at: <http://www.zirany.eu/ kultura/pamiatky.php>

ŠIMEK, P. 2001. Evaluation of trees and their stands for growing purposes in gardening. Lednice : Dissertation thesis, 2001, $159 \mathrm{p}$.

TÓTH, A. - VEREŠOVÁ, M. 2018. Small Sacral Architecture and Trees as Monuments in Diverse Cultural Landscapes of Slovakia. In Plants in urban areas and landscape, At Nitra, 2018, pp. 7-13. ISBN 978-80-552-1829-8.

MACHOVEC, J. 1987. Evaluation of greenery in urban parks. In Životné prostredie, vol. 21, 1987, no. 3, pp. 134-139.

VEGA1/0371/18. 2018. SakralArch: Preservation of the Historical Legacy and Architectural Diversity of Small Sacral Structures in Cultural Landscape of Slovakia. 